\title{
HUBUNGAN MANAGERIAL OVERCONFIDENCE, KEPEMILIKAN PEMERINTAH DAN KEPUTUSAN PEMBIAYAAN PERUSAHAAN
}

\author{
Dewi Puji Lestari \\ Faisal Faisal \\ Departemen Akuntansi, Fakultas Ekonomika dan Bisnis \\ Universitas Diponegoro, Semarang. \\ fe_faisal@yahoo.co.id
}

\begin{abstract}
This study examines the effect of managerial overconfidence on corporate financing which measured by leverage ratio. Also it investigates the moderating effect of government ownership on the relationship between managerial overconfidence and leverage. The managerial overconfidence is measured by photo profile, degree of education, experience, gender and network. The sample consists of 176 public companies listed on Indonesia Stock Exchange in 2017. The results of this study show that managerial overconfidence proxied by photo profile has a negatively effect on leverage. Other results find that experience and network positively affect on leverage. However, this study failed to show that level of education, gender, government ownership have significant effect on leverage. In addition, government ownership does not act as a moderating variable that influence the relationship between managerial overconfidence and leverage. The implications of this study suggest that the personal characteristics of manager such as profile, experience and network should be considered as factors that may influence level of corporate financing.
\end{abstract}

Keywords: managerial overconfidence, government ownership, financing, leverage, upper echelon theory

\section{PENDAHULUAN}

Keberlangsungan jangka panjang perusahaan dipengaruhi oleh keputusan keuangan yang diambil oleh manajer keuangan. Setiap pengambilan keputusan bertujuan untuk memaksimalkan peningkatan nilai perusahaan. Salah satu tantangan yang sering dihadapi oleh manajer keuangan yaitu menentukan struktur modal yang optimal (Ting \& Lean, 2011). Hal yang umumnya dipertanyakan dalam menentukan struktur modal adalah seberapa banyak utang yang diperlukan untuk mengoptimalkan nilai perusahaan (Hull, 2011). Besarnya nilai leverage menunjukan proporsi hutang yang besar pada keputusan pembiayaan perusahaan. Pengambilan keputusan pembiayaan yang salah dapat menyebabkan perusahaan mengalami kesulitan keuangan dan berujung pada kebangkrutan.

Faktor penentu dalam keputusan pembiayaan perusahaan selalu menjadi isu yang menarik untuk menjadi bahan diskusi (Wei, Min \& Jiaxing, 2011). Beberapa penelitian telah membahas isu tersebut (Chen, Jiang, \& Lin, 2014; Hull, 2011; Ting \& Lean, 2011). Menurut Ting et al. (2016), dalam membahas faktor penentu struktur modal, teori keuangan tradisional hanya berfokus pada karakteristik fundamental perusahaan dalam membahas keputusan 
pembiayaan perusahaan. Oliver (2005) menyebutkan bahwa teori keuangan tradisional umumnya berorientasi pada faktor-biaya agensi, asimetri informasi dan biaya transaksi. Hal yang membedakan pilihan keuangan perusahaan dengan perusahaan lainnya walaupun memiliki data dasar yang sama dapat dijelaskan dengan teori perilaku (Tomak, 2013).

Barros \& Silveira (2009) menyatakan bahwa teori keuangan tradisional memiliki asumsi bahwa manajer perusahaan bertindak secara rasional. Namun, nyatanya, pengambilan keputusan yang dilakukan seorang manajer jauh dari definisi rasional. Ketika manajer tidak rasional, mereka cenderung menaksir dengan tinggi dan meremehkan dalam membuat keputusan perusahaan. Manajer yang bias dalam pengambilan keputusan akan berpengaruh terhadap keberlangsungan perusahaan. Sikap bias seorang manajer ini mengarah pada sikap overconfidence.

Huang et al (2016) menyatakan bahwa overconfidence terbukti mempunyai dampak yang besar terhadap pengambilan keputusan perusahaan. Dalam hal keputusan akuisisi, Brown \& Sarma (2007) menyatakan bahwa CEO cenderung melakukan akuisisi. Deshmukh, Goel, \& Howe (2013) menyatakan bahwa tingkat pembayaran dividen lebih rendah di perusahaan yang dikelola oleh CEO yang overconfidence. Hal ini karena CEO memandang bahwa pendanaan eksternal lebih mahal dibandingkan pendanaan internal sehingga mengurangi pembayaran dividen untuk kebutuhan investasi. Menurut Hackbarth (2008), dalam pengambilan keputusan pembiayaan perusahaan, CEO yang overconfidence percaya bahwa perusahaan akan lebih untung dan berisiko rendsh jika mereka menggunakan pembiayaan dengan utang. Bank yang memiliki CEO yang overconfidence cenderung menyetujui banyak pinjaman sehingga pada saat krisis terjadi mereka menderita kerugian modal yang lebih besar dari kredit macet yang menyebabkan penurunan kekayaan bersih yang lebih besar (Ho et al, 2016).

Sebagai ilustrasi, pada tahun 2010, perusahaan Sime Darby yang merupakan perusahaan perkebunan terkemuka di dunia yang bertempat di Malaysia mengalami kerugian sebesar 2,1 miliar rupiah. Menurut Tingetal. (2016), kerugianinidisebabkan oleh pelanggaran kepercayaan yang dilakukan oleh pemimpin perusahaaan dan terlalu tingginya dalam pilihan investasi. Akibat kasus tersebut perusahaan Sime Darby telah mempengaruhi tingkat kepercayaan para investor di pasar saham. Abor (2007) menyatakan bahwa kepercayaan investor dihasilkan dari tata kelola yang baik. Berdasarkan kasus tersebut, maka perlu disoroti perlunya aspek personal manusia, khususnya karakteristik CEO sebagai pengambil keputusan perusahaan.

Chief Executive Officer(CEO) memegang peran penting dalam menentukan banyak kebijakan perusahaan dan cukup beralasan dikatakan sebagai representasi perusahaan dihadapan para investor. Li et al. (2016) menyatakan bahwa di beberapa perusahaan, keputusan mengenai kinerja dan citra perusahaan diambil oleh CEO. Istilah CEO di Indonesia lebih dikenal sebagai direktur utama perusahaan. Para pemegang saham menunjuk dewan komisaris dalam upaya untuk melindungi nilai investasi mereka di perusahaan tersebut dan untuk memonitor para eksekutif puncak perusahaan. Para direktur utama diharapkan dapat membuat kebijakan-kebijakan yang meningkatkan nilai perusahaan. Namun, sikap yang dimiliki oleh para manajer puncak dapat mempengaruhi keputusan-keputusan perusahaan tersebut. Penelitian ini secara lebih spesifik akan membahas bias keperilakuan overconfidence di kalangan manajer puncak dan menguji dampaknya terhadap leverage perusahaan.

Selain perusahaan Sime Darby, Malaysia Airlines juga mengalami kerugian sebelum pajak sebesar RM523. Kedua kasus ini memiliki kesamaan yaitu perusahaan 
tersebut merupakan government linked companies(GLCs). MenurutTing etal. (2016), government linked companies didefinisikan sebagai perusahaan yang memilik tujuan utama komersial dan pemerintah Malaysia memiliki saham pengendali langsung. GLCs memiliki kemiripan yang erat dengan perusahaan swasta dan menjadi institusi nasional yang penting di Malaysia. Untuk di Indonesia government linked companies dikenal sebagai badan usaha milik negara (BUMN).

Menurut UU No. 19 Tahun 2003, badan usaha milik negara atau yang disingkat dengan BUMN merupakan badan usaha yang modalnya baik sebagian ataupun seluruhnya dimiliki oleh negara. BUMN memiliki peran vital dalam perekonomian. BUMN dibentuk dengan tujuan memberikan sumbangan dalam perkembangan perekonomian yang berperan dalam menghasilkan barang dan jasa untuk kesejahteraan rakyat. BUMN terdapat dalam berbagai sektor yakni pertanian, perkebunan, kehutanan, keuangan, manufaktur, transportasi, pertambangan, telekomunikasi dan perdagangan serta konstruksi.

BUMN memiliki pemerintah sebagai pemegang saham perusahaan. Pemerintah memiliki tujuan politik dan sosial. Hal ini seringkali membuat perbedaan tujuan antara pemerintah dengan pemegang saham selain pemerintah serta tidak sejalan dengan tujuan perusahaan. Perbedaan tujuan ini memberikan pengaruh terhadap keputusan perusahaan. Sebagian manajer di BUMN adalah pegawai negeri yang tidak memiliki ketajaman bisnis dan keputusan investasi mereka lebih bersifat politis (Ting \& Lean, 2011). Oleh karena itu, perlu diketahui bagaimana kepemilikan pemerintah mempengaruhi perilaku perusahaan dan keputusan perusahaan.

Penelitian Ting et al. (2016) menyatakan bahwa hubungan managerialoverconfidence berpengaruh secara negatif terhadap leverage dan kepemilikan pemerintah dapat memoderasi hubungan antara managerial overconfidence dan leverage perusahaan, bergantung pada persentase kepemilikan pemerintah pada perusahaan tersebut. Penelitian mengenai pengaruh managerial overconfidence, kepemilikan pemerintah dan leverage perusahaan masih jarang dilakukan khususnya di Indonesia. Di Indonesia, penelitian terkait managerial overconfidence telah dilakukan oleh Murhadi (2018). Penelitian tersebut membahas mengenai pengaruh managerial overconfidence terhadap leverage perusahaan tanpa membahas adanya pengaruh moderasi dari kepemilikan pemerintah. Maka, penelitian ini bertujuan untuk menganalisis pengaruh managerial overconfidence terhadap leverage perusahaan dan juga apakah adanya dengan kepemilikan pemerintah mampu memoderasi hubungan antara managerial overconfidence dengan leverage pada perusahaan yang terdaftar di Bursa Efek Indonesia. Berdasarkan latar belakang diatas, maka permasalahan dalam penelitian ini dapat dirumuskan sebagai berikut : 1. Apakah managerial overconfidence berpengaruh terhadap leverage ? 2. Apakah kepemilikan pemerintah berpengaruh terhadap leverage ? 3 . Apakah kepemilikan pemerintah mampu memoderasi hubungan antara managerial overconfidence dengan leverage?

\section{TINJAUAN PUSTAKA}

\section{Upper Echelon Theory}

Hambrick dan Mason (1984) dalam upper echelon theory menyatakan bahwa karakteristik latar belakang manajerial memprediksi sebagian outcomes organisasi seperti pilihan strategis dan tingkat organisasi. Teori ini memandang bahwa outcomes organisasi merupakan hasil dari karakteristik manajer puncak. Manajer puncak sebagai pengambil keputusan dalam organisasi memiliki tanggung jawab atas keseluruhan organisasi sehingga apa yang mereka lakukan dan bagaimana prosesnya serta karakteristik manajer puncak itu sendiri 
mempengaruhi outcomes organisasi. Ting et al. (2016) menyatakan bahwa semakin penting karakteristik pribadi pembuat keputusan bergantung oleh kompleksitas suatu keputusan. Situasi yang dihadapi pembuat keputusan adalah kompleks dan fenomena yang jauh dari yang mereka bisa pahami sehingga dasar kognitif dan nilai yang dibawa oleh pembuat keputusan menjadi filter antara situasi dan persepsi dalam pengambilan keputusan (Hambrick \& Mason, 1984).

Upper echelon theory menyatakan bahwa karakteristik pribadi yang dapat mempengaruhi dalam membuat keputusan seperti umur, jalur fungsional, pengalaman karir, latar belakang pendidikan, latar belakang sosial ekonomi, posisi keuangan dan karakteristik grup. Menurut Hambrick \& Mason (1984) bahwa usia dapat mempengaruhi dilihat dari sikap manajer yang lebih tua yakni manajer yang lebih tua memiliki kemampuan fisik dan mental yang lebih sediki terkait mengintegrasi informasi serta tingkat keyakinan untuk membuat keputusan. Lalu manajer cenderung untuk mempertahankan keadaan tetap perusahaan dan menghindari risiko demi mempertahankan kemananan finansial maupun karir.
Menurut Hambrick \& Mason (1984), jalur fungsional mungkin tidak mendominasi namun diharapkan dapat memberikan pengaruh terhadap pengambilan keputusan. Pengalaman manajer pucak dapat memberikan prediksi dari peluang dan masalah. Manajer yang berasal dari luar perusahaan cenderung melakukan perubahan terhadap struktur maupun prosedur. Manajer puncak hanya bekerja pada satu perusahaan selama karirnya maka cenderung memiliki pengetahuan yang terbatas sehingga berpengaruh terhadap keputusan yang akan diambil. Selanjutnya latar belakang pendidikan diharapkan menunjukan pengaruh terhadap keputusan. Latar belakang pendidikan dikaitkan dengan inovasi dan risiko. Menurut upper echelon theory bahwa latar belakang pendidikan hanya sebagai variabel moderasi. Misalnya seseorang yang menempuh pendidikan S2 cenderung menghindari risiko.

Hambrick \& Mason (1984) menyatakan latar belakang sosial ekonomi menunjukan strategi pertumbuhan dari perusahaan. Seorang manajer yang berasal dari latar belakang yang rendah cenderung melakukan diversifikasi dan strateginya bersifat agresif karena mengejar pengakuan serta penghargaan. Posisi keuangan memiliki

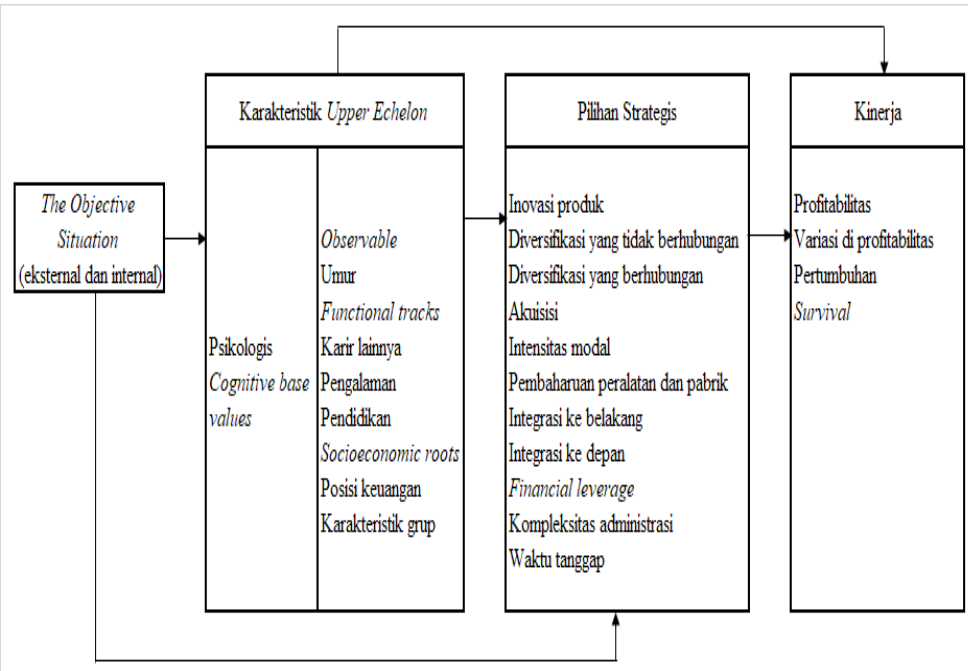

Gambar 1. Kerangka Upper Echelon

Sumber: Hambrick \& Mason (1984), 
pengaruh terhadap strategi perusahaan. Apabila manajer memiliki pendapatan yang cukup maka akan mengejar tujuan non ekonomi dan karakteristik grup berpengaruh terhadap preferensi perusahaan dengan melihat pengaruhnya terhadap konflik. Perusahaan yang lebih bersifat homogen cenderung cepat dalam pengambilan keputusan.

\section{Hubungan Antara Managerial Overconfidence dan Leverage}

Barros \& Silveira (2009) menyatakan bahwa overconfidence diidentifikasi sebagai kecenderungan untuk melebih-lebihkan pengetahuan dan keterampilan dan/atau ketepatan dan kualitas informasi yang diperoleh. Dalam pengambilan keputusan, Fairchild (2009) menyatakan overconfident manager akan melebihkan perkiraan profitabilitas dan meremehkan risiko terkait pada proyek investasi perusahaan. Maka, manajer akan meremehkan kemungkinan financial distress dan memilih hutang sebagai sumber pembiayaannya. Hambrick \& Canella (2004) juga menunjukkan bahwa overconfident manager lebih memilih level hutang yang lebih tinggi. Dalam pengambilan keputusan, mereka cenderung berinvestasi sehingga ketika berinvestasi akan menerbitkan lebih banyak hutang. Penelitian Wang et al (2013) menunjukkan bahwa managerial oveconfidence memberikan pengaruh yang positif terhadap pemilihan hutang.

Namun tidak semua penelitian menunjukkan pengaruh postif managerial overconfidence terhadap keputusan pembiayaan perusahaan. Menurut Ting et al. (2016), perusahaan yang memiliki manajer yang overconfident cenderung memiliki tingkat hutang yang lebih rendah. Maka terdapat pengaruh negatif dari managerial overconfidence karena manajer yang overconfident beranggapan bahwa proyek baru akan meningkatkan nilai perusahaan sehingga akan memilih mengurangi tingkat hutang. Dalam kasus proyek baru,
Fairchild (2009) juga menyatakan pengaruh negatif atas overconfidence. Wei et al. (2011) menyatakan bahwa overconfident manager melemahkan hubunga positif antara debt maturity structure dan struktur aset. Penelitian yang dilakukan oleh Tomak (2013) menyatakan bahwa managerial overconfidence tidak berpengaruh atas keputusan pembiayaan perusahaan.

Dalam menentukan managerial overconfidence, setiap penelitian melihat dari aspek yang berbeda-beda. Penelitian Barros \& Silveira (2009) menggunakan pengklasifikasian antara pengusaha dan bukan pengusaha sebagai alat untuk mengukur overconfidence. Sedangkan penelitian Tomak (2013) menggunakan consumer confidence index yang dikeluarkan Universitas Michigan dalam menentukan overconfidence. Menurut Ting et al. (2016) dan Murhadi (2018), managerial overconfidence dapat diukur dengan karakteristik pribadi direktur utama perusahaan. Karakteristik pribadi ini seperti ukuran foto profil direktur utama, tingkat pendidikan, pengalaman, gender dan jaringan. Berdasarakan uraian diatas, managerial overconfidence dapat diukur dengan karakteristik pribadi direktur utma perusahaan dan pengaruhnya terhadap leverage menunjukan pola yang tidak konsisten. Oleh karena itu, penulis mengajukan hipotesis pertama yaitu:

H1a: Managerial overconfidence yang diukur dengan foto profil memiliki pengaruh terhadap leverage.

H1b: Managerial overconfidence yang diukur dengan tingkat pendidikan memiliki pengaruh terhadap leverage.

H1c: Managerial overconfidence yang diukur dengan pengalaman memiliki pengaruh terhadap leverage.

H1d: Managerial overconfidence yang diukur dengan gender memiliki pengaruh terhadap leverage.

H1e: Managerial overconfidence yang diukur dengan jaringan memiliki pengaruh terhadap leverage. 


\section{Hubungan Antara Kepemilikan \\ Pemerintah dan Leverage}

BUMN memiliki pemerintah sebagai pemegang saham perusahaan. Diyanty (2010) menjelaskan antara pemerintah dan pemegang saham selain pemerintah terkadang tidak sejalan karena adanya perbedaan tujuan. Perbedaan tujuan ini memberikan pengaruh terhadap keputusan yang diambil perusahaan. Menurut Kassim et al. (2012) dalam industri yang dikendalikan oleh negara, CEO sadar bahwa mereka dipantau dan dinilai oleh dewan sehingga akan berkinerja lebih baik. Namun Ting \& Lean (2011) menyatakan bahwa sebagian manajer di BUMN yang merupakan pegawai negeri yang tidak memiliki ketajaman bisnis dan keputusan investasi.

Penelitian yang dilakukan Ting et al. (2016) menunjukan kepemilikan pemerintah berpengaruh secara positif terhadap leverage. Perusahaan dimana pemerintah sebagai pemegang sahamnya cenderung memilih hutang sebagai pembiayaan perusahaan. Berdasarkan penelitian tersebut juga, kepemilikan pemerintah memoderasi secara negatif hubungan antara managerial overconfidence dengan leverage. Sedangkan pada penelitian Huang \& Song (2006) yang melakukan uji pada perusahaan di China menunjukkan bahwa struktur modal tidak dipengaruhi oleh kepemilikan institusional mempertimbangkan efek pajak dalam pembiayaan hutang jangka panjang.

Berdasarkan uraian diatas menunjukan pola yang tidak konsisten mengenai pengaruh kepemilikan pemerintah serta adanya pengaruh moderasi managerial overconfidence terhadap leverage. Oleh karena itu, penulis mengajukan hipotesis kedua dan ketiga yaitu:

$\mathrm{H} 2$ : Kepemilikan pemerintah memiliki pengaruh terhadap leverage.

H3a: Kepemilikan pemerintah memoderasi hubungan antara managerial overconfidence yang diukur foto profil dengan leverage.

$\mathrm{H} 3 \mathrm{~b}$ : Kepemilikan pemerintah memoderasi hubungan antara managerial overconfidence yang diukur tingkat pendidikan dengan leverage.

H3c: Kepemilikan pemerintah memoderasi hubungan antara managerial overconfidence yang diukur pengalaman dengan leverage.

H3d: Kepemilikan pemerintah memoderasi hubungan antara managerial overconfidence yang diukur jaringan dengan leverage.

\section{METODE PENELITIAN \\ Variabel Penelitian dan Definisi Operasional}

Leverage merupakan variabel dependen dalam penelitian. Rasio leverage dilambangkan dengan LEVE. Rajan \& Zingales (1995) menyatakan rasio leverage menunjukan karakteristik hutang perusahaan. Rasio leverage dapat dihitung dengan menggunakan rumus:

$$
\text { Leverage }=\frac{\text { Total Liabilitas }}{\text { Total Aset }}
$$

Managerial overconfidence merupakan variabel independen dalam penelitian. Dalam mendefinisikan managerial overconfidence menggunakan lima ukuran managerial overconfidence berdasarkan karakteristik pribadi direktur utama yaitu foto profil, tingkat pendidikan, pengalaman, gender, dan jaringan direktur utama. Peneliti menggunakan variabel foto profil dalam menentukan seorang direktur utama perusahaan adalah seorang yang percaya diri atau tidak. Ting et al. (2016) mengukur variabel foto profil dengan melihat foto direktur utama perusahaan yang terdapat pada laporan tahunan perusahaan. Apabila foto direktur utama berukuran satu atau setengah halaman di laporan tahunan akan diberi empat poin. Jika ukurannya kurang dari setengah halaman diberi tiga poin. Apabila terdapat individu lain bersama direktur utama maka diberi dua poin dan 
satu poin jika tidak ada foto direktur utama. Rakhmayil \& Yuce (2013) menyatakan bahwa hutang perusahaan dipengaruhi secara positif oleh tingkat pendidikan yang lebih tinggi dan banyaknya pengalaman kerja. Mengacu pada penelitian Ting et al. (2016), pengukuran tingkat pendidikan direktur utama menggunakan skala berkisar 1-7. Poin satu diberikan jika direktur utama tidak lulus SMA. Poin dua diberikan jika lulus dari SMA. Poin tiga jika mengikuti sekolah tinggi atau universitas. Poin empat jika mendapat gelar S-1 atau diploma. Poin lima jika mengikuti sekolah pasca sarjana. Poin enam jika mendapat gelar S-2. Poin tujuh jika mendapat gelar doktor.

Direktur utama akan membawa pengalaman yang sebelumnya didapatkan ke perusahaan baru. Direktur utama yang lebih banyak pengalaman lebih percaya diri dan berhati-hati terhadap bias pada saat mengambil keputusan. Penulis mengikuti penelitian Yang et al. (2011) dalam mengukur pengalaman direktur utama yaitu dengan menggunakan ukuran satu jika menjabat sebagai eksekutif seperti direktur keuangan, direktur operasional atau wakil direktur perusahaan di perusahaan lain sebelum bergabung dengan perusahaan sekarang. Jika tidak diberi kode nol.

Nekby et al. (2008) menyatakan perempuan lebih percaya diri dibandingkan dengan laki-laki. Namun penelitan Huang \& Kisgen (2013) menyatakan sebaliknya yakni laki-laki lebih percaya diri daripada perempuan. Direktur utama laki-laki cenderung melakukan akuisisi serta menerbitkan hutang dibandingkan saham dalam pembiayaannya Pengukuran gender direktur utama menggunakan variabel dummy. Kode satu jika direktur utama adalah laki-laki dan nol jika perempuan.

March \& Saphira (dikutip oleh Ting et al. 2016) menyatakan bahwa direktur utama lebih percaya diri dan berhati-hati terhadap bias keputusan ketika juga menjabat sebagai anggota dewan atau pengurus perusahaan lain. Pengukuran jaringan direktur utama mengikuti penelitian Yang et al. (2011) dilakukan dengan menghitung jumlah dewan di perusahaan direktur utama bekerja selain perusahaan direktur utama sendiri ditambah dengan jumlah organisasi nirlaba yang direktur utama menjabat sebagai anggota dewan

Sekaran (2003) menyatakan variabel pemoderasi merupakan variabel yang memiliki efek kontigensi yang kuat pada hubungan variabel dependen dan variabel indepen. Kepemilikan pemerintah merupakan variabel pemoderasi dalam penelitian. Kepemilikan pemerintah didefinisikan sebagai persentase saham perusahaan yang dimiliki oleh pemerintah. Penelitian ini menggunakan lima variabel kontrol yaitu profitabilitas, ukuran perusahaan, tangibility ratio, kesempatan investasi dan pertumbuhan perusahaan.

Return on Asset (ROA) merupakan salah satu bentuk rasio profitabilitas untuk mengukur kemampuan perusahaan dalam menghasilkan laba. Menurut Ting \& Lean (2011), trade off theory menyatakan bahwa perusahaan cenderung untuk menerbitkan hutang ketika laba tinggi untuk meminimalkan beban pajak. ROA mengukur efektivitas dari penggunaan aset perusahaan.

$$
\text { Profitabilitas }=\frac{\text { Laba Sebelum Pajak }}{\text { Total Aset }}
$$

Ukuran perusahaan menggambarkan besarnya aset yang dimiliki perusahaan. Menurut Ting \& Lean (2011), perusahaan besar kurang memperhatikan permasalahan yang timbul dalam menerbitkan ekuitas, sehingga perusahaan besar cenderung menggunakan ekuitas sebagai pembiaayaannya.

\section{Ukuran Perusahaan=log(Total Aset)}

Aset berwujud menunjukkan jumlah kekayaan perusahaan yang dapat dijadikan jaminan. Menurut Rajan \& Zingales (1995) 
semakin besar proporsi aset yang berwujud maka semakin besar keinginan kreditor dalam memberikan pinjaman. Tangibility dapat dihitung dengan menggunakan rumus:

$$
\text { Tangibility }=\frac{\text { Aset Tetap }+ \text { Persediaan }}{\text { Total Aset }}
$$

Menurut Lin dan Zeng (2013) manajer cenderung berinvestasi di proyek yang memberikan keuntungan dalam waktu singkat. Hal ini dengan tujuan untuk menginkatkan reputasi manajer untuk meningkatkan jenjang karir. Kesempatan investasi diproksikan dengan rasio dari intangible assets. Rasio ini dapat dihitung dengan menggunakan rumus:

$$
\text { Kesempatan Investasi }=\frac{\text { Aset Tidak Berwujud }}{\text { Total Aset }}
$$

Menurut Ting dan Lean (2011), bank cenderung untuk memberikan pinjaman kepada perusahaan yang memiliki peluang pertumbuhan yang baik. Pertumbuhan perusahaanmerupakan persentase perubahan tahunan dari total penjualan. Growth dapat dihitung dengan menggunakan rumus:

Pertumbuhan $=\frac{\text { Penjualan }_{t}-\text { Penjualan }_{t-1}}{\text { Penjualan }_{t-1}}$

Dalam menentukan sampel, peneliti menggunakan purposive sampling atau pengambilan sampel yang memenuhi kualifikasi yang telah ditentukan. Kriteria yang ditetapkan dalam memilih sampel adalah sebagai berikut: 1. Perusahaan sektor non keuangan yang telah tercatat di Bursa Efek Indonesia pada 2017. 2. Perusahaan yang memiliki kelengkapan data yang dibutuhkan dalam pengujian.

Pengujian hipotesis pada penelitian ini menggunakan analisis regresi berganda untuk menguji hipotesis. Analisis ini digunakan untuk mengetahui adanya pengaruh dari variabel independen terhadap variabel dependen. Model statistik untuk menguji hipotesis penelitian ditunjukkan sebagai berikut:

\begin{tabular}{|c|c|}
\hline & \\
\hline$E D U_{i t}$ & = Pendidikan direktur utama \\
\hline$E X P_{i t}^{i t}$ & $=$ Pengalaman direktur utama \\
\hline$G E N_{i t}$ & = Gender direktur utama \\
\hline$N E T_{i t}$ & = Jaringan direktur utama \\
\hline$G V O_{i t}$ & $=$ Kepemilikan pemerintah \\
\hline$R O A_{i t}$ & $=$ Profitabilitas \\
\hline$S I Z E_{i t}$ & $=$ Ukuran perusahaan \\
\hline TANG $_{i t}$ & $=$ Tangibility ratio \\
\hline & = Kesempatan investasi \\
\hline $\begin{array}{l}\text { GROWTH }_{i t} \\
(\times 1 \times m)_{i t}\end{array}$ & $\begin{aligned}= & \text { Pertumbuhan perusahaan } \\
= & \text { Interaksi antara foto profil } \\
& \text { direktur utama dan leverage }\end{aligned}$ \\
\hline$(x 2 \times m)_{i t}$ & $\begin{aligned}= & \text { Interaksi antara tingkat } \\
& \text { pendidikan direktur utama } \\
& \text { dan leverage }\end{aligned}$ \\
\hline$(x 3 \times m)_{i t}$ & $\begin{aligned}= & \text { Interaksi antara pengalaman } \\
& \text { direktur utama dan leverage }\end{aligned}$ \\
\hline$(x 4 \times m)_{i t}$ & $\begin{aligned}= & \text { Interaksi antara gender } \\
& \text { direktur utama dan leverage }\end{aligned}$ \\
\hline$\alpha$ & $=$ Koefisien regresi \\
\hline it $\mathrm{Q}$ & $\begin{array}{l}=\text { Perusahaan dan indeks } \\
\text { tahun }\end{array}$ \\
\hline & $=$ Error \\
\hline
\end{tabular}

$$
\begin{aligned}
& L E V E_{i t}=\alpha_{0}+\alpha_{1} P P_{i t}+\alpha_{2} E D U_{i t}+\alpha_{3} E X P_{i t}+\alpha_{4} G E N_{i} \\
& +\alpha_{5} N E T_{i t}+\alpha_{6} G V O_{i t} \\
& +\alpha_{7} R O A_{i t}+\alpha_{8} S I Z E_{i t}+\alpha_{9} T A N G_{i t}+\alpha_{10} R \& D_{i t} \\
& +\mathrm{a}_{11} G R O W T H_{i t} \\
& +\alpha_{12}(\times m)_{i t}+\alpha_{13}(\times m)_{i t}+\alpha_{14}(\times m)_{i t} \\
& +\alpha_{15}(\times m)_{i t}+\sum \alpha_{i} \text { Year }_{i} \\
& +\sum \alpha_{t} \text { Industry }{ }_{t}+\varepsilon_{i t}
\end{aligned}
$$

Keterangan:

\section{ANALISIS DAN PEMBAHASAN}

Penelitian ini bertujuan untuk mengidentifikasi pengaruh managerial 
overconfidence dan kepemilikan pemerintah terhadap leverage. Untuk menguji hal tersebut, peneliti menentukan perusahaan non keuangan yang terdaftar di Bursa Efek Indonesia sebagai populasi. Kemudian dalam menentukan sampel penelitian menggunakan metode purposive sampling. Kriteria yang digunakan yaitu perusahaan yang terdaftar di Bursa Efek Indonesia pada tahun 2017 dan memiliki seluruh data yang digunakan dalam penelitian. Penjelasan mengenai objek penelitian ditampilkan pada tabel 1.

\begin{tabular}{lc}
\multicolumn{2}{c}{ Tabel 1 Sampel Penelitian } \\
\hline \multicolumn{1}{c}{ Kriteria } & Jumlah \\
\hline $\begin{array}{l}\text { Perusahaan non keuangan yang } \\
\text { tercatat di BEl tahun } 2017\end{array}$ & 484 \\
$\begin{array}{l}\text { Perusahaan yang tidak memiliki } \\
\text { kelengkapan data yaitu aset tidak } \\
\text { berwujud }\end{array}$ & 308 \\
Sampel penelitian & 176 \\
\hline
\end{tabular}

Tabel 2 Statistik Deskriptif

\begin{tabular}{lcccccc}
\hline Variabel & N & Median & Rata-rata & $\begin{array}{c}\text { St. } \\
\text { Deviasi }\end{array}$ & Maksimum & Minimum \\
\hline LEVE & 176 & 0.48 & 0.48 & 0.2 & 1.05 & 0.04 \\
PP & 176 & 3.00 & 2.61 & 0.62 & 4 & 1 \\
EDU & 176 & 4.00 & 4.81 & 1.24 & 7 & 1 \\
EXP & 176 & 1.00 & 0.74 & 0.44 & 1 & 0 \\
GEN & 176 & 1.00 & 0.92 & 0.27 & 1 & 0 \\
NET & 176 & 0.00 & 0.78 & 1.43 & 10 & 0 \\
GVO & 176 & 0.00 & 0.05 & 0.17 & 0.9 & 0 \\
ROA & 176 & 0.04 & 0.05 & 0.97 & 0.41 & -0.31 \\
SIZE & 176 & 28.23 & 29.11 & 1.78 & 33.32 & 19.61 \\
TANG & 176 & 0.44 & 0.46 & 0.24 & 1.71 & 0.01 \\
R\&D & 176 & 0.01 & 0.04 & 0.08 & 0.5 & 0 \\
GROWTH & 176 & 0.07 & 0.72 & 4.67 & 43.07 & -16.05 \\
\hline & & & & & & \\
\hline
\end{tabular}

Berdasarkan Tabel 1, maka disimpulkan jumlah sampel penelitian yang digunakan untuk analisis dan pengujian hipotesis yaitu sebesar 176. Dari seluruh objek penelitian yang merupakan perusahaan BUMN hanya sebesar $7,39 \%$ dari keseluruhan objek penelitian sehingga hal ini dapat mempengaruhi pengujian terhadap penelitian terutama yang hipotesis dua dan tiga yang menggunakan variabel kepemilikan pemerintah. Tabel 2 menyajikan statistik deskriptif untuk setiap variabel.

Keterangan: LEVE: leverage, PP: Foto profil, EDU: latar belakang pendidikan, EXP: pengalaman, GEN: gender, NET: jaringan, GVO: kepemilikan pemerintah, ROA: profitabilitas, SIZE: ukuran perusahaan, R\&D: kesempatan investasi, GROWTH: pertumbuhan perusahaan.

Pengujian normalitas dilakukan dengan uji kolmogorov-smirnov. Hasil kolmogorovsmirnov ditunjukan pada Tabel 3.

Tabel 3 Hasil Uji Normalitas

\begin{tabular}{lc}
\hline & Unstandardized Residual \\
\hline Test Statistic & 0,042 \\
\hline $\begin{array}{l}\text { Asymp. Sig. } \\
\text { (2-tailed) }\end{array}$ & 0,200 \\
\hline
\end{tabular}

Berdaarkan hasil pengujian menggunakan uji kolmogorov-smirnov, nilai $Z$ atau $Z$-value sebesar 0.042 dengan nilai signifikansi sebesar 0.200 sehingga telah memenuhi asumsi normalitas. Oleh karena itu, dapat diambil kesimpulann bahwa data terdistribusi secara normal dengan nilai asymp sig sebesar 0.200 yang lebih besar dari 0.05 .

Tabel 4 menunjukan variabel PP, EDU, EXP, GEN, NET, ROA, SIZE, TANG, R\&D dan GROWTH tidak terdapat multikolonieritas. Sedangkan variabel GVO menunjukan nilai tolerance lebih besar dari 0.1 dan nilai VIF kurang dari 10. Maka diketahui bahwa terjadi korelasi antar variabel di dalam model regresi. Hal ini disebabkan oleh jumlah sampel penelitian yang merupakan BUMN hanya sebesar $7,39 \%$ dari total sampel penelitian. 
Tabel 4 Hasil Uji Multikolonieritas

\begin{tabular}{cccc} 
Variabel & Tolerance & VIF & Kesimpulan \\
\hline PP & 0,932 & 1,072 & $\begin{array}{c}\text { Tidak terdapat } \\
\text { multikolonieritas }\end{array}$ \\
\hline EDU & 0,883 & 1,133 & $\begin{array}{c}\text { Tidak terdapat } \\
\text { multikolonieritas }\end{array}$ \\
\hline GEN & 0,943 & 1,060 & $\begin{array}{c}\text { Tidak terdapat } \\
\text { multikolonieritas }\end{array}$ \\
\hline NET & 0,952 & 1,051 & $\begin{array}{c}\text { Tidak terdapat } \\
\text { multikolonieritas }\end{array}$ \\
\hline GVO & 0,808 & 1,237 & $\begin{array}{c}\text { Tidak terdapat } \\
\text { multikolonieritas }\end{array}$ \\
\hline ROA & 0,896 & 1,115 & $\begin{array}{c}\text { Tidak terdapat } \\
\text { multikolonieritas }\end{array}$ \\
\hline SIZE & 0,853 & 1,173 & $\begin{array}{c}\text { Tidak terdapat } \\
\text { multikolonieritas }\end{array}$ \\
\hline TANG & 0,904 & 1,107 & $\begin{array}{c}\text { Tidak terdapat } \\
\text { multikolonieritas }\end{array}$ \\
\hline R\&D & 0,886 & 1,129 & $\begin{array}{c}\text { Tidak terdapat } \\
\text { multikolonieritas }\end{array}$ \\
\hline GROWTH & 0,970 & 1,031 & $\begin{array}{c}\text { Tidak terdapat } \\
\text { multikolonieritas }\end{array}$ \\
\hline
\end{tabular}

Tabel 5 Hasil Uji Heteroskedastisitas

\begin{tabular}{|c|c|c|c|}
\hline Variabel & $t$ & Sig & Kesimpulan \\
\hline PP & $-1,282$ & 0,202 & $\begin{array}{c}\text { Tidak terdapat } \\
\text { heteroskedastisitas }\end{array}$ \\
\hline EDU & $-0,737$ & 0,462 & $\begin{array}{l}\text { Tidak terdapat } \\
\text { heteroskedastisitas }\end{array}$ \\
\hline EXP & 0,864 & 0,389 & $\begin{array}{c}\text { Tidak terdapat } \\
\text { heteroskedastisitas }\end{array}$ \\
\hline GEN & 0,647 & 0,518 & $\begin{array}{c}\text { Tidak terdapat } \\
\text { heteroskedastisitas }\end{array}$ \\
\hline NET & $-0,781$ & 0,436 & $\begin{array}{c}\text { Tidak terdapat } \\
\text { heteroskedastisitas }\end{array}$ \\
\hline GVO & 0,336 & 0,737 & $\begin{array}{c}\text { Tidak terdapat } \\
\text { heteroskedastisitas }\end{array}$ \\
\hline ROA & $-0,456$ & 0,649 & $\begin{array}{c}\text { Tidak terdapat } \\
\text { heteroskedastisitas }\end{array}$ \\
\hline SIZE & $-1,773$ & 0,078 & $\begin{array}{c}\text { Tidak terdapat } \\
\text { heteroskedastisitas }\end{array}$ \\
\hline TANG & 0,107 & 0,915 & $\begin{array}{c}\text { Tidak terdapat } \\
\text { heteroskedastisitas }\end{array}$ \\
\hline R\&D & $-0,674$ & 0,501 & $\begin{array}{c}\text { Tidak terdapat } \\
\text { heteroskedastisitas }\end{array}$ \\
\hline $\begin{array}{c}\text { GROWT } \\
\mathrm{H}\end{array}$ & 1,344 & 0,181 & $\begin{array}{c}\text { Tidak terdapat } \\
\text { heteroskedastisitas }\end{array}$ \\
\hline
\end{tabular}

Tabel 6 Hasil Uji Regresi

\begin{tabular}{|c|c|c|c|c|}
\hline Variabel & $\mathrm{N}$ & Koefisien & $t$ & $P$-value \\
\hline PP & 176 & $-0,048$ & $-2,159$ & 0,032 \\
\hline EDU & 176 & $-0,007$ & $-0,606$ & 0,546 \\
\hline EXP & 176 & 0,069 & 2,249 & 0,026 \\
\hline GEN & 176 & 0,041 & 0,808 & 0,420 \\
\hline NET & 176 & 0,020 & 2,193 & 0,030 \\
\hline GVO & 176 & 1,090 & 1,226 & 0,222 \\
\hline ROA & 176 & $-0,904$ & 6,373 & 0,000 \\
\hline SIZE & 176 & 0,003 & $-0,411$ & 0,682 \\
\hline TANG & 176 & 0,051 & 0,916 & 0,361 \\
\hline R\&D & 176 & 0,423 & 2,608 & 0,010 \\
\hline GROWTH & 176 & $-0,001$ & $-0,335$ & 0,738 \\
\hline $\mathrm{x} 1^{*} \mathrm{~m}$ & 176 & 0,092 & 0,297 & 0,767 \\
\hline$x 2^{*} \mathrm{~m}$ & 176 & $-0,049$ & $-0,431$ & 0,667 \\
\hline$x 3^{*} \mathrm{~m}$ & 176 & $-0,463$ & $-1,337$ & 0,183 \\
\hline $\mathrm{x} 4^{*} \mathrm{~m}$ & 176 & $-0,482$ & $-0,745$ & 0,458 \\
\hline R-Squared & 176 & & 0,360 & \\
\hline $\begin{array}{l}\text { Adjusted } \\
R \text {-Squared }\end{array}$ & 176 & & 0,300 & \\
\hline F-Statistic & 176 & & 6,012 & \\
\hline $\begin{array}{l}P \text { (Signifi- } \\
\text { kansi) }\end{array}$ & 176 & & 0,000 & \\
\hline
\end{tabular}

Tabel 5, menunjukan hasil uji heteroskedastisitas menggunakan uji glejser. Berdasarkat tabel tersebut, nilai signifikansi lebih besar dari 0.05 , sehingga dapat disimpulkan bahwa penelitian tidak terjadi masalah heteroskedastisitas.

\section{PEMBAHASAN \\ Pengaruh Managerial Overconfidence yang Diukur Foto Profil Terhadap Leverage}

Hasil penelitian menunjukan bahwa hipotesis yang diajukan yaitu pengaruh managerial overconfidence yang diukur foto profil terhadap leverage diterima. Hasil penelitian ini konsisten dengan hasil penelitian dari Ting et al.(2016) bahwa 
Tabel 7

Ringkasan Hasil Uji Hipotesis

\begin{tabular}{|c|c|c|c|}
\hline Hipotesis & $\mathrm{t}$ & Sig. & Kesimpulan \\
\hline $\begin{array}{l}\text { Managerial overconfidence yang diukur foto profil memiliki pengaruh } \\
\text { terhadap leverage }\end{array}$ & $-2,159$ & 0,032 & $\begin{array}{l}\text { H1a } \\
\text { didukung }\end{array}$ \\
\hline $\begin{array}{l}\text { Managerial overconfidence yang diukur tingkat pendidikan memiliki } \\
\text { pengaruh terhadap leverage }\end{array}$ & 0,606 & 0,546 & H1b ditolak \\
\hline $\begin{array}{l}\text { Managerial overconfidence yang diukur pengalaman memiliki pengaruh } \\
\text { terhadap leverage }\end{array}$ & 2,249 & 0,026 & $\begin{array}{l}\text { H1c } \\
\text { didukung }\end{array}$ \\
\hline $\begin{array}{l}\text { Managerial overconfidence yang diukur gender memiliki pengaruh } \\
\text { terhadap leverage }\end{array}$ & 0,808 & 0,420 & H1d ditolak \\
\hline $\begin{array}{l}\text { Managerial overconfidence yang diukur jaringan memiliki pengaruh } \\
\text { terhadap leverage }\end{array}$ & 2,193 & 0,030 & $\begin{array}{l}\text { H1e } \\
\text { didukung }\end{array}$ \\
\hline Kepemilikan pemerintah memiliki pengaruh terhadap leverage & 1,226 & 0,222 & H2 ditolak \\
\hline $\begin{array}{l}\text { Kepemilikan pemerintah memoderasi hubungan antara managerial } \\
\text { overconfidence yang diukur foto profildengan leverage }\end{array}$ & 0,297 & 0,767 & H3a ditolak \\
\hline $\begin{array}{l}\text { Kepemilikan pemerintah memoderasi hubungan antara managerial } \\
\text { overconfidence yang diukur tingkat pendidikan dengan leverage }\end{array}$ & $-0,431$ & 0,667 & H3b ditolak \\
\hline $\begin{array}{l}\text { Kepemilikan pemerintah memoderasi hubungan antara managerial } \\
\text { overconfidence yang diukur pengalaman dengan leverage }\end{array}$ & $-1,337$ & 0,183 & H3c ditolak \\
\hline $\begin{array}{l}\text { Kepemilikan pemerintah memoderasi hubungan antara managerial } \\
\text { overconfidence yang diukur gender dengan leverage }\end{array}$ & $-0,745$ & 0,458 & H3d ditolak \\
\hline
\end{tabular}

terdapat pengaruh negatif dari managerial overconfidence yang diukur dengan foto profil terhadap leverage. Ukuran foto profil yang besar menunjukan seorang direktur utama lebih rasional.Hal ini karena jati diri dan fotonya diketahui oleh orang lain sehingga ia akan berhati-hati dalam pengambilan keputusan. Direktur utama yang rasional akan memilih pembiayaan yang lebih aman dan kurang berisiko. Oleh karena itu, semakin besar ukuran foto profil direktur utama yang ditampilkan, maka perusahaan cenderung untuk menggunakan ekuitas dalam pembiayannya dibandingkan menggunakan hutang.

\section{Pengaruh Managerial \\ Overconfidence yang Diukur Tingkat PendidikanTerhadap Leverage}

Hasil penelitian menunjukan bahwa hipotesis yang diajukan yaitu pengaruh managerial overconfidence yang diukur tingkat pendidikan terhadap leverage ditolak.
Menurut Koriat et al. (dikutip oleh Wei et al, 2011) semakin tinggi tingkat pendidikan maka semakin banyak pengetahuan yang dimiliki sehingga membuat mereka lebih berhati-hati dan lebih rasional. Direktur utama yang rasional lebih memilih ekuitas sebagai pembiayaannya. Hal ini sejalan dengan penelitian Ting et al.(2016) bahwa terdapat pengaruh managerial overconfidence yang diukur dengan tingkat pendidikan direktur utama berpengaruh terhadap leverage pada perusahaan non keuangan di Malaysia. Penelitian yang dilakukan Murhadi (2018) pada perusahaan non keuangan di Indonesia juga konsisten dengan penelitian Ting et al.(2016). Namun penelitian ini sejalan dengan upper echelon theory bahwa tingkat pendidikan hanya sebagai variabel moderasi dalam outcomes perusahaan. Tingkat pendidikan dikaitkan dengan inovasi dan risiko sehingga mempengaruhi keputusan perusahaan. 


\section{Pengaruh Managerial Overconfidence yang Diukur Pengalaman Terhadap Leverage}

Hasil penelitian menunjukan bahwa hipotesis yang diajukan yaitu pengaruh managerial overconfidence yang diukur pengalaman terhadap leverage diterima. Menurut upper echelon theory bahwa pengalaman direktur utama berkaitan dengan peluang dan masalah. Direktur utama yang hanya bekerja pada satu perusahaan selama karir mereka cenderung memiliki pengetahuan yang terbatas apabila dihadapkan dengan masalah yang belum pernah terjadi sebelumnya. Sehingga direktur utama yang hanya memiliki sedikit pengalaman cenderung memiliki kepercayaan diri yang berlebihan (Wei et al, 2011). Kepercayaan diri yang berlebihan membuat direktur utama lebih memilih pembiayaan yang berisiko. Maka, perusahaan dengan tingkat managerial overconfidence yang tinggi cenderung menggunakan hutang sebagai sumber pembiayaannya. Penelitian ini juga sejalan dengan penelitian yang diakukan Murhadi (2018) yang menyatakan bahwa managerial overconfidence yang diukur dengan pengalaman berpengaruh positif terhadap leverage. Oleh karena itu, perusahaan dengan tingkat managerial overconfidence yang tinggi cenderung menggunakan hutang.

\section{Pengaruh Managerial Overconfidence yang Diukur Gendee Terhadap Leverage}

Hasil penelitian menunjukan bahwa hipotesis yang diajukan yaitu terdapat pengaruh managerial overconfidence yang diukur variabel gender terhadap leverage ditolak. Hal ini tidak sejalan dengan penelitian Ting et al. (2016) yang menyatakan bahwa ada pengaruh negatif dari managerial overconfidence yang diukur gender terhadap leverage pada perusahaan non keuangan di Malaysia. Akan tetapi penelitian ini konsisten dengan penelitian yang dilakukan Murhadi (2018). Penelitian menunjukan bahwa tidak ada pengaruh dari managerial overconfidence yang diukur dengan variabel gender terhadap leverage. Hal ini disebabkan penunjukan perempuan sebagai direktur utama dikarenakan adanya hubungan kekeluargaan atau hanya ingin melakukannya saja dan bukan karena faktor keahlian dan pengalaman (Suherman 2017).

\section{Pengaruh Managerial Overconfidence yang Diukur Jaringan Terhadap Leverage}

Hasil penelitian menunjukan bahwa hipotesis yang diajukan yaitu terdapat pengaruh managerial overconfidence yang diukur jaringan terhadap leverage diterima. Hal ini sejalan dengan penelitian Ting et al. (2016) dan Murhadi (2018) bahwa terdapat pengaruh managerial overconfidence yang diukur dengan jaringan terhadap leverage. Jaringan berkaitan dengan aksesibilitas informasi. Yang et al. (2011) menyatakan direktur utama yang memiliki jaringan yang baik memiliki akses yang lebih cepat terhadap informasi. Akses yang lebih cepat membuat direktur utama memiliki kepercayaan diri yang berlebihan karena menerima informasi yang lebih cepat dibanding yang lainnya dan juga tidak melihat keakuratan dari informasi. Hal ini membuat direktur utama memilih pengambilan keputusan yang berisiko. Oleh karena itu direktur utama yang juga memiliki memiliki jabatan di perusahaan lain cenderung untuk menggunakan hutang sebagai pembiayaannya dibandingkan ekuitas.

\section{Pengaruh Kepemilikan \\ PemerintahTerhadap Leverage}

Hasil penelitian menunjukan bahwa hipotesis yang diajukan yaitu terdapat pengaruh kepemilikan pemerintah terhadap keputusan pembiayaan perusahaan ditolak. Hal ini sejalan dengan penelitian Huang \& Song (2006) bahwa tidak ada pengaruh 
kepemilikan pemerintah terhadap leverage pada perusahaan di China. Penelitian tersebut menyatakan bahwa tidak terdapatnya pengaruh dari kepemilikan pemerintah karena sebagian perusahaan yang terdaftar di bursa adalah perusahaan yang dimiliki sehinga pemerintah sebagai pemiliki perusahaan sekaligus penerima pajak. Selain itu pemerintah merupakan pemegang saham pengendali, jika perusahaan tidak mengubah perilaku maka cenderung terjadi krisis dibandingkan perusahaan yang pemegang saham pengendalinya adalah swasta. Namun hasil pada penelitian ini bukan disebabkan karena mempertimbangkan efek pajak. Akan tetapi mungkin disebabkan karena dari sampel penelitian hanya 13 perusahaan dari total 176 perusahaan yang dijadikan objek penelitian yang merupakan perusahaan BUMN.

\section{Pengaruh Kepemilikan Pemerintah Dalam Memoderasi Hubungan Antara Managerial Overconfidence Dengan Leverage}

Hasil penelitian menunjukan bahwa tidak terdapat pengaruh moderasi dari kepemilikan pemerintah terhadap hubungan antara managerial overconfidence dengan leverage. Semua variabel interaksi managerial overconfidence yang diukur dengan variabel foto profil, tingkat pendidikan, pengalaman, gender dan jaringan menunjukan hasil yang konsisten. Penelitian ini tidak sejalan dengan penelitian Ting et al. (2016), bahwa terdapat pengaruh moderasi dari kepemilikan pemerintah terhadap hubungan antara managerial overconfidence dengan leverage. Perusahaan di Malaysia yang memiliki pemerintah memiliki saham yang besar pada perusahaan akan memperlemah hubungan antara managerial overconfidence dengan leverage. Namun pada penelitian ini, menunjukan tidak ada pengaruh moderasi dari kepemilikan pemerintah. Hal ini mungkin disebabkan karena hanya $7,39 \%$ dari total objek penelitian yang terdapat pemerintah sebagai pemegang saham.

\section{SIMPULAN}

Penelitian ini bertujuan untuk menguji pengaruh managerial overconfidence dan kepemilikan pemerintah serta adanya interaksi managerial overconfidence dan kepemilikan perusahaan terhadap leverage perusahaan. Sampel penelitian yang digunakan yaitu perusahaan non keuangan yang terdaftar di Bursa Efek Indonesia (BEI) tahun 2017. Penentuan sampel menggunakan purposive sampling, yakni dipilih berdasarkan kualifikasi yang telah ditentukan. Hasil penelitian ini menunjukkan bahwa: Pertama, managerial overconfidence yang diukur dengan variabel foto profil berpengaruh negatif terhadap leverage. Kedua, managerial overconfidence yang diukur dengan variabel tingkat pendidikan tidak berpengaruh terhadap leverage. Ketiga, managerial overconfidence yang diukur dengan variabel pengalaman berpengaruh positif terhadap leverage. Keempat, managerial overconfidence yang diukur dengan variabel gender tidak berpengaruh terhadap leverage. Kelima, managerial overconfidence yang diukur dengan variabel jaringan berpengaruh positif terhadap leverage. Keenam, kepemilikan pemerintah tidak memoderasi hubungan antara managerial overconfidence yang diukur foto profil terhadap leverage. Ketujuh, kepemilikan pemerintah tidak memoderasi hubungan antara managerial overconfidence yang diukur tingkat pendidikan terhadap leverage. Kedelapan, kepemilikan pemerintah tidak memoderasi hubungan antara managerial overconfidence yang diukur pengalaman terhadap leverage. Kesembilan, kepemilikan pemerintah tidak memoderasi hubungan antara managerial overconfidence yang diukur gender terhadap 
leverage.

Dalam melaksanakan penelitian ini, peneliti menemukan adanya keterbatasan bahwa hanya $7,39 \%$ dari total objek penelitian yang merupakan BUMN sehingga kemungkinan mempengaruhi hasil penelitian. Penelitian dapat mempertimbangkan pengukuran lain dari kepemilikan seperti kepemilikan asing atau institusional yang kemungkinan dapat mempengaruhi keputusan pembiayaan perusahaan.

\section{DAFTAR PUSTAKA}

Abor, Joshua. 2007. "Corporate Governance and Financing Decisions of Ghanaian Listed Firms." The International Journal of Effective Board Performance 7(1):83-92.

Barros, Lucas Ayres B.de c and Alexander Di Miceli da Silveira. 2009. "Overconfidence, Managerial Optimism and the Determinants of Capital Structure." Brazilian Review Of Finance 6(3):293-335.

Brown, Rayna and Neal Sarma. 2007. "CEO Overconfidence, CEO Dominance and Corporate Acquisitions." Journal of Economics and Business 59(5):358-79.

Chen, Jian, Chunxia Jiang, and Yujia Lin. 2014. "What Determine Firms' Capital Structure in China ?" Managerial Finance 40(10):1024-39.

Deshmukh, Sanjay, Anand M. Goel, and Keith M. Howe. 2013. "CEO Overconfidence and Dividend Policy." Journal of Financial Intermediation 22(3):440-63. Retrieved (http:// dx.doi.org/10.1016/j.jfi.2013.02.00).

Diyanty, Vera. 2010. "Analisis Pengaruh Kepemilikan Pemerintah Dan Keputusan Keuangan Terhadap Kinerja Perusahaan: Studi Terhadap Perusahaan Pemerintah Yang Listed Di BEI." Jurnal Akuntansi 10(2):155-80.

Fairchild, Richard. 2009. "Managerial Overconfidence, Moral Hazard Problems, and Excessive Life-Cycle Debt Sensitivity ." Investment Management and Financial Innovations 6(3):35-42.

Ghozali, I. (2013). Aplikasi Analisis Multivariete dengan Program IBM SPSS 23 (Vol. 8). Semarang: Universitas Diponegoro.

Hackbarth, Dirk. 2008. "Managerial Traits and Capital Structure Decisions." Journal of Financial and Quantitative Analysis 43(4):843-81.

Hambrick, Donald C. and Albert A. Cannella. 2004. "CEOS Who Have COOS: Contingency Analysis of An Unexplored Structural Form." Strategic Management Journal 25(10):959_ 79.

Hambrick, Donald C. and Phyllis A. Mason. 1984. "Upper Echelons: The Organization as a Reflection of Its Top Managers." Academy of Management Review 9(2):193-206.

Ho, Po-hsin, Chia-wei Huang, Chih-yung Lin, and Ju-fang Yen. 2016. "CEO Overconfidence and Financial Crisis: Evidence from Bank Lending and Leverage." Journal of Financial Economics. Retrieved (http://dx.doi.org/10.1016/j.fineco.2015.04.007).

Huang, Guihai and Frank M. Song. 2006. "The Determinants of Capital Structure : Evidence from China." China Economic Review 17(1):14-36.

Huang, Jiekun and Darren J. Kisgen. 2013. "Gender and Corporate Finance: Are Male Executives Overconfident Relative to Female Executives? \$." Journal of Financial Economics 108(3):822-39.

Huang, Ronghong, Kelvin Jui Keng Tan, and Robert W. Faff. 2016. "CEO Overconfidence and 
Corporate Debt Maturity." Journal of Corporate Finance 36:93-110.

Hull, Robert M. 2011. "Debt-Equity Decision-Making With and Without Growth." Managerial Finance 37(8):765-87.

Irene Wei Kiong Ting, Hooi Hooi Lean, Qian Long Kweh, and Noor Azlinna Azizan. 2016. "Managerial Overconfidence, Government Intervention and Corporate Financing Decision." International Journal Of Managerial Finance 12(1):4-24.

Kassim, Aza Azlina, Zuaini Ishak, Nor Aziah, and Abdul Manaf. 2012. "Board Process, Capital Structure Decisions and Company Performance.” 6(1):81-87.

Li, Frank, Tao Li, and Dylan Minor. 2016. "CEO Power, Corporate Social Responsibility, and Firm Value : A Test of Agency Theory." International Journal Of Managerial Finance 12(5):611-28.

Lin, Horn-chern and Tao Zeng. 2013. "Ownership Structure and R\&D Spending : Evidence from China's Listed Firms." Chinese Management Studies 5(1):82-93.

Murhadi, Werner Ria. 2018. "Managerial Cverconfidence and Firm Financing Decision : An Indonesian Case." Advances in Social Science, Education and Humanities Research 186:71-75.

Nekby, Lena, Peter Skogman Thoursie, and Lars Vahtrik. 2008. "Gender and Self-Selection into a Competitive Environment : Are Women More Overcon Fi Dent than Men ? $\square$." Economics Letters 100(3):405-7.

Oliver, Barry R. 2005. "The Impact of Management Confidence on Capital Structure." 1-23.

Rajan, Raghuram G. and Luigi Zingales. 1995. "What Do We Know about Capital Structure ? Some Evidence from International Data." The Journal Of Finance 50(5):1421-60.

Rakhmayil, Sergiy and Ayse Yuce. 2013. "Executive Qualification and Firm Value." Journal of Applied Business and Economics 14(5):52-70.

Sekaran, Uma. 2003. Research Methods For Business.

Subramanyam and Wild. 2014. Analisis Laporan Keuangan. Jakarta: Salemba Empat.

Suherman. 2017. "Apakah Diversitas Gender Memengaruhi Struktur Modal? Bukti Empiris Di Indonesia." 21(2):218-27.

Ting, Irene Wei Kiong and Hooi Hooi Lean. 2011. "Capital Structure Of Goverment-Linked Companies In Malaysia." Asian Academy of Management Journal of Accounting and Fnance 7(2):137-56.

Tomak, Serpil. 2013. "The Impact of Overconfidence on Capital Structure in Turkey." International Journal of Economics and Financial Issues 3(2):512-18.

Wang, Chih-yung, Yu-fen Chen, and Chia-wen Yu. 2013. "Managerial Optimism and PostFinancing Stock Performance in Taiwan : A Comparison of Debt and Equity Financing." Economics Letters 119(3):332-35.

Wei, Jiang, Xiao Min, and You Jiaxing. 2011. "Managerial Overconfidence and Debt Maturity Structure of Firms Analysis Based on China's Listed Companies." China Finance Review International 1(3):262-79.

Yang, Qin, Monica Zimmerman, and Crystal Jiang. 2011. "An Empirical Study of the Impact of CEO Characteristics on New Firms â€ $€^{\mathrm{TM}}$ Time to IPO." Journal of Small Business Management 49(2):163-84. 